\title{
Correction to: The long non-coding RNA SAMMSON is essential for uveal melanoma cell survival
}

\begin{abstract}
Shanna Dewaele (D), Louis Delhaye (D), Boel De Paepe (D), Eric James de Bony (D), Jilke De Wilde, Katrien Vanderheyden, Jasper Anckaert (D), Nurten Yigit (iD, Justine Nuytens (D), Eveline Vanden Eynde (D), Joél Smet, Maxime Verschoore, Fariba Nemati, Didier Decaudin, Manuel Rodrigues (D), Peihua Zhao, Aart Jochemsen (D), Eleonora Leucci (D), Jo Vandesompele (iD, Jo Van Dorpe, Jean-Christophe Marine, Rudy Van Coster, Sven Eyckerman (D) and Pieter Mestdagh (D)
\end{abstract}

(c) The Author(s) 2021

Oncogene (2022) 41:146; https://doi.org/10.1038/s41388-021-02051-6

Correction to: Oncogene https://doi.org/10.1038/s41388-021-02006-x, published online 10 September 2021

In this article the affiliation details for Author Jean-Christophe Marine were incorrectly given as Laboratory for RNA Cancer Biology, Department of Oncology, KU Leuven, Leuven, Belgium. but should have been Laboratory for Molecular Cancer Biology, Center for Cancer Biology, VIB, Leuven, Belgium; Laboratory for Molecular Cancer Biology, Department of Oncology, KU Leuven, Leuven, Belgium.

The original article has been corrected. (c) Open Access This article is licensed under a Creative Commons adaptation, distribution and reproduction in any medium or format, as long as you give appropriate credit to the original author(s) and the source, provide a link to the Creative Commons license, and indicate if changes were made. The images or other third party material in this article are included in the article's Creative Commons license, unless indicated otherwise in a credit line to the material. If material is not included in the article's Creative Commons license and your intended use is not permitted by statutory regulation or exceeds the permitted use, you will need to obtain permission directly from the copyright holder. To view a copy of this license, visit http://creativecommons. org/licenses/by/4.0/.

(c) The Author(s) 2021 